\title{
Abordaje Terapéutico en un Adulto con Neumonía Recurrente, Inmunodeficiencia Común Variable y Hepatitis B crónica
}

\author{
Andrés Felipe Zea-Vera MD PhDandres.zea@correounivalle.edu.co \\ Profesor Asistente. Dpto Microbiologia, Universidad del Valle.
}

INTRODUCCION: El reemplazo con inmunoglobulinas es el pilar de la terapia para los pacientes con inmunodeficiencia común variable (CVID), que se caracteriza por ser una inmunodeficiencia predominantemente de anticuerpos siendo además la inmunodeficiencia primaria (IDP) más frecuente. Los sujetos con hepatitis $B$ crónica han sido excluidos sistemáticamente de los estudios clínicos en que se evalúa el reemplazo de inmunoglobulinas en pacientes con IDP y en consecuencia, no se ha evaluado su eficacia y seguridad

DESCRIPCION DEL CASO: Hombre afro-colombiano de 27 años de edad que se presentó al servicio de urgencias de un hospital nivel III de la ciudad de Cali (Colombia). Al examen fisico y por imagen se demuestra una neumonía basal izquierda con derrame. Tiene como antecedente neumonias a repetición (más de 10 neumonias en su vida adulta) desde los 22 años de edad, más de 10 pruebas ELISA de 4 ta generación) y un total de 3 fibrobroncoscopias donde le realizaron estudios para tuberculosis negativos. Los hemocultivos y cultivo de esputo fueron positivos para Streptococcus pneumoniae multisensible. Inmunología clínica de adultos hace el diagnostico de infección crónica por Hepatitis $B$ inmuno-tolerante e inmunodeficiencia humoral grave, con niveles de inmunoglobulinas en rangos de agamaglobulinemia (Tabla 1). La hipogamaglobulinemia grave con cantidad de linfocitos B normal y las infecciones sinopulmonares establecen con certeza el diagnóstico de inmuno deficiencia común variable (CVID).

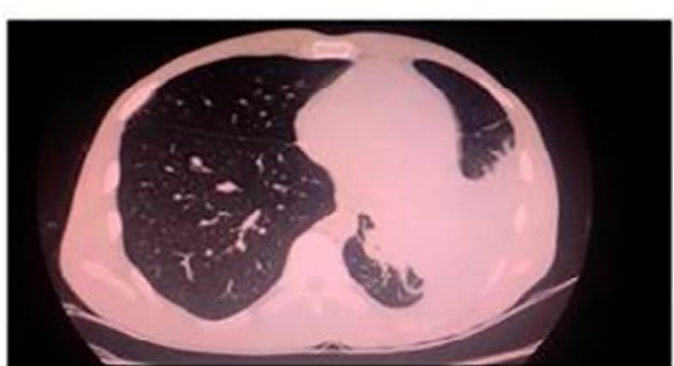

Figura 1: Consolidación basal izquierda con derrame ipsilateral con diagnostico microbiológico de Streptococcus pnoumonibe

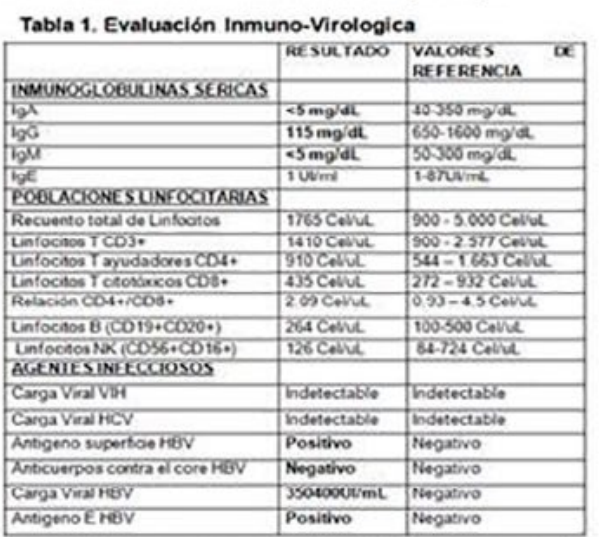

PROPUESTA TERAPEUTICA: Sustitución con inmunoglobulinas humanas intravenosa IVIg: 1. Inicio de entecavir buscando reducir al máximo la carga viral 2. Profilaxis con Trimetoprim/sulfametoxazol sumado aazitromicina de rescate en caso de síntomas respiratorios. 3. Evaluación periódica del HBsAg, carga viral de VHB y las enzimas hepáticas. 4. Hidratación pre-administracion de IVIg 5. Premedicación: Prednisolona/Cetirizina 6 . Inmunoglobulina Humana intravenosa (IVIg) al 10\%. La IVIg se inicio a una dosis de $100 \mathrm{mg} / \mathrm{kg}$ interdiaria, para una dosis acumulada de $500 \mathrm{mg} / \mathrm{kg}$. 7. Pruebas de función renal y hepática.

CONCLUSIÓN: La supresión de HBV con entecavir y la administración inicial de dosis bajas inmunoglobulina humana intravenosa al $10 \%(100 \mathrm{mg} / \mathrm{Kg}$ interdiarias hasta lograr la dosis acumulada indicada) a baja velocidad de infusión, puede ser una estrategia eficazy segura en el tratamiento de pacientes con CVID y hepatitis $B$ crónica. 